\title{
Utilization of Nonradiative Excited State Dissipation for Promoted Phototheranostics Based on an AIE-Active Type I ROS Generator
}

Yifei Wang, ${ }^{1,2}$ Yudong Sun, ${ }^{1,2}$ Jiabing Ran, ${ }^{1,2}$ Huiran Yang, ${ }^{1,2}$ Shuzhang Xiao, ${ }^{1,2}$ Jing Yang, ${ }^{1,2}$ Changying Yang, ${ }^{* 1,2}$ Huimin Wang ${ }^{* 1,2}$ and Yi Liu ${ }^{* 3}$

\author{
${ }^{1}$ Hubei Key Laboratory of Natural Products Research and Development, China Three Gorges University, Yichang443002, China. \\ ${ }^{2}$ College of Biological and Pharmaceutical Science, China Three Gorges University, Yichang443002, China. \\ ${ }^{3}$ State Key Laboratory of Separation Membrane and Membrane Process, School of Chemistry and Chemical Engineering \& School of \\ Environmental Science and Engineering, Tiangong University, Tianjin 300387, China. \\ *Address correspondence to changying.yang@ectgu.edu.cn.
}




\section{Table of Contents}

Experimental detailsScheme . S2

Scheme S1. The synthetic routes to NS-TPA and NS-STPA. $\mathrm{S} 12$

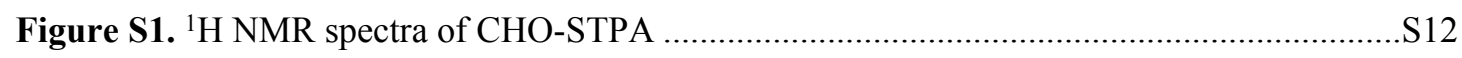

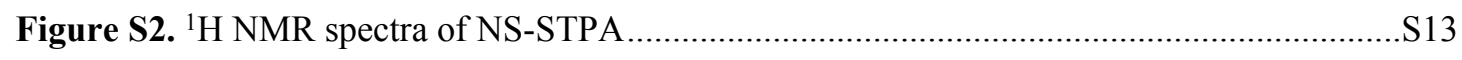

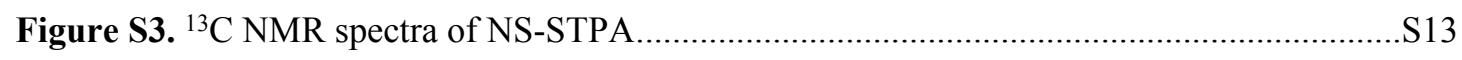

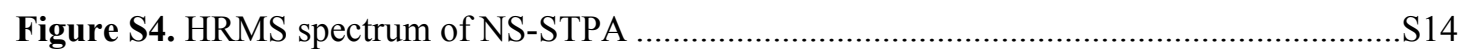

Figure S5. Spectra behaviors of NS-TPA and NS-STPA in different solvents polarities .............S14

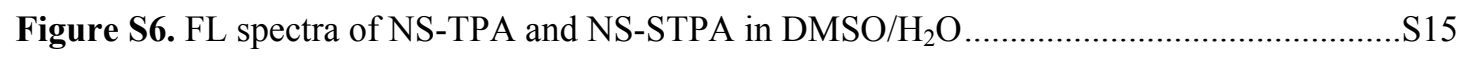

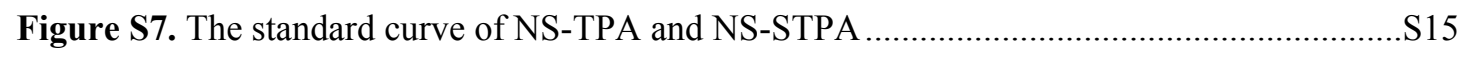

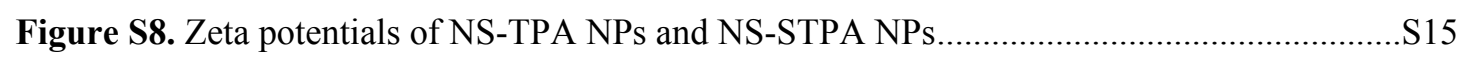

Figure S9. Photothermal conversion behaviors of NS-TPA NPs and NS-STPA NPs...................S16

Figure S10. IR thermal images of NS-STPA and NS-STPA NPs .............................................. 17

Figure S11. ROS detection of NS-TPA NPs and NS-STPA NPs under $660 \mathrm{~nm}$ laser .................S17

Figure S12. ROS detection of NS-TPA NPs and NS-STPA NPs under $530 \mathrm{~nm}$ laser ..................S18

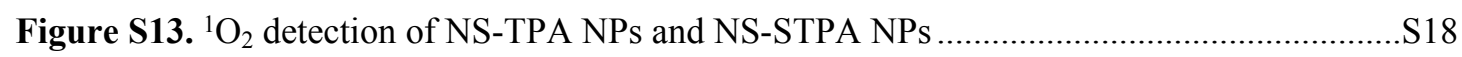

Figure S14. ROS detection of NS-STPA NPs in different states ${ }^{\bullet} \mathrm{OH}$......................................... 19

Figure S15. ${ }^{\bullet} \mathrm{OH}$ detection of NS-STPA NPs in different oxygen environment ..........................S20

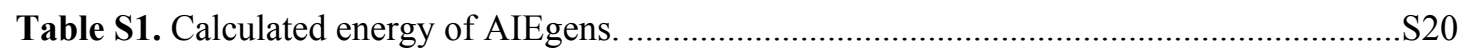

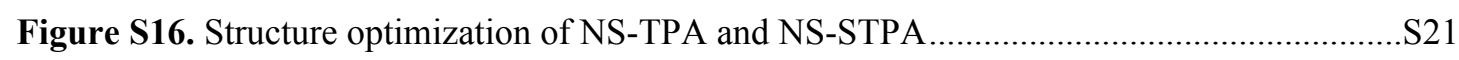

Table S2. Spin-orbit coupling matrix elements calculation of NS-TPA .......................................S2

Table S3. Spin-orbit coupling matrix elements calculation of NS-STPA ....................................S22

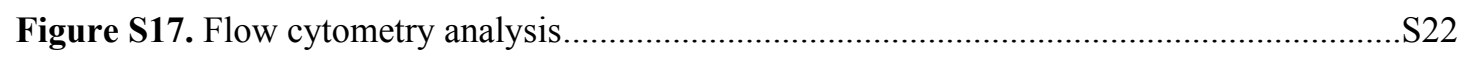

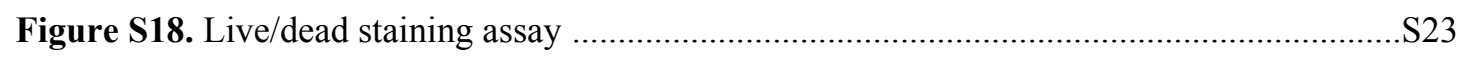

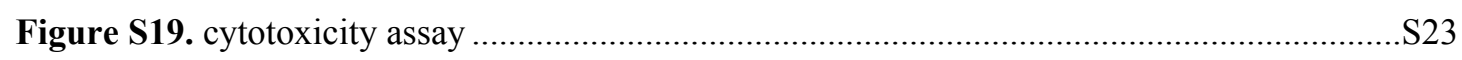

Figure S20. Fluorescence imaging assay of control group ......................................................... 24

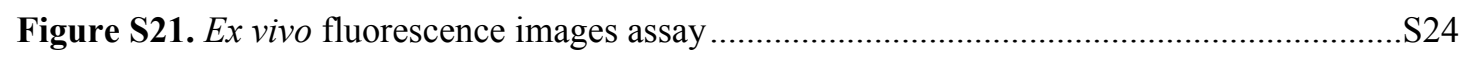

Figure S22. In vivo thermal images assay of control group........................................................S24

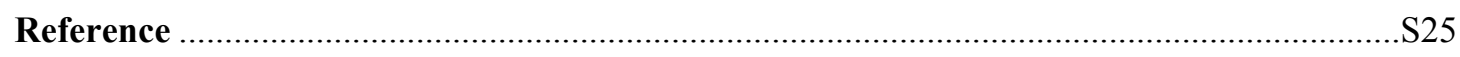




\section{Experimental details}

\section{Materials and Instruments}

All reagents, catalysts, and solvents were purchased from commercial suppliers and used without further purification unless otherwise stated. Column chromatography was carried out using silica gel (200-300 mesh). NMR spectra were recorded on a Bruker ADVANCE III (400 MHz) spectrometer. DMSO-d6, Methanol-d4, Trichloromethane-d1 and Acetone-d6 is a solvent for NMR analysis, and tetramethylsilane (TMS) is used as an internal standard. MS measurements were performed on an Agilent 6530 Q-TOF LC/MS. Fluorescence spectra were obtained using a Hitachi F-4600 fluorescence spectrometer. UV-vis absorption spectra were measured on a Shimadzu U-2600 UV-vis spectrophotometer. Dynamic light scattering (DLS) experiments for measuring the size distribution of nanoparticles aqueous solution were performed on a Zetasizer nano ZSE (Malvern Instruments, UK). The morphology of nanoparticles was observed by Transmission Electron Microscope (TEM, JEM-F200, Japan). Cell imaging tests were carried out on Nikon A1R+ confocal microscopy (Nikon, Japan).

\section{Density functional theory calculations}

Geometry optimization for AIEgens were performed in $\mathrm{H}_{2} \mathrm{O}$ media with the SMD solvent model using the Gaussian 09 program package at B3LYP/6-31G** level. The energies of $\mathrm{S}_{1}$ and $\mathrm{T}_{1}$ state of AIEgens were calculated by Time-dependent density functional theory (TD-DFT) method in $\mathrm{H}_{2} \mathrm{O}$ media with the SMD solvent model.

Synthesis and Characterization of the NS-STPA.

Synthesis of NS. $1.99 \mathrm{~g}(0.01 \mathrm{~mol})$ 2-methyl-b-nathphothiazole and2.44 g (0.02 mol) 1,3-propane sultone were refluxed for $6 \mathrm{~h}$ in $4.0 \mathrm{ml}$ dichlorobenzene. The solution was then cooled to room temperature and diluted with $20 \mathrm{~mL}$ acetone and $30 \mathrm{~mL}$ anhydrous ethanol. The resulting precipitate was then collected by filtration to yield $1.134 \mathrm{~g} \mathrm{(35 \% )}$ of beige solid.

Synthesis of OHC-STPA. 5-formyl-2-thiopheneboronic acid $1.55 \mathrm{~g}$ (0.01 mol), 4-Bromotriphenylamine $3.88 \mathrm{~g}(0.012 \mathrm{~mol})$ and tetrakis (triphenyl phosphine) palladium (0) (0.3 mmol) were degassed and purged with $\mathrm{N}_{2}$ for three times. $\mathrm{THF} / \mathrm{H}_{2} \mathrm{O}=9: 1(30 \mathrm{~mL})$ and $2.5 \mathrm{M} \mathrm{K}_{2} \mathrm{CO}_{3}$ were injected into the reaction via 
syringe. After heating the reaction mixture at $80^{\circ} \mathrm{C}$ for $18 \mathrm{~h}$, water $(10 \mathrm{~mL})$ and dichloromethane $(20 \mathrm{~mL})$ were then added. Collected the organic phase and dried over anhydrous MgSO4. After evaporation, the crude product was purified by silia gel column using dichloromethane/petroleum ether $(1: 2, \mathrm{v} / \mathrm{v})$ as eluant, and then the resulting bright yellow solid was obtained ( $40 \%$ yield). ${ }^{1} \mathrm{H}$ NMR (400 MHz, Acetone-d6): $\delta 9.95$ (s, 1H), 7.97 (d, $\left.J=4.0 \mathrm{~Hz}, 1 \mathrm{H}\right), 7.75$ $-7.69(\mathrm{~m}, 2 \mathrm{H}), 7.59(\mathrm{~d}, J=4.0 \mathrm{~Hz}, 1 \mathrm{H}), 7.44-7.35(\mathrm{~m}, 4 \mathrm{H}), 7.21-7.14(\mathrm{~m}$, $6 \mathrm{H}), 7.11-7.04(\mathrm{~m}, 2 \mathrm{H})$.

Synthesis of NS-STPA. A mixture of $0.321 \mathrm{~g}(1.0 \mathrm{mmol}) \mathrm{NS}, 0.355 \mathrm{~g}(1.0$ mmol) OHC-STPA and $0.2 \mathrm{ml}$ piperidine in $6.0 \mathrm{ml}$ anhydrous ethanol were refluxed for $8 \mathrm{~h}$. Then the reaction was cooled to room temperature. The precipitated solid was collected by filtration at reduced pressure and washed with cold ethanol. Ultimately, the crude product was purified by column chromatography using dichloromethane and methanol $(v / v=20 / 1)$ as the eluent to give a red powder (65\% yield). ${ }^{1} \mathrm{H}$ NMR (400 MHz, DMSO-d6) $\delta 8.84$ (d, $J$ $=8.8 \mathrm{~Hz}, 1 \mathrm{H}), 8.43-8.33(\mathrm{~m}, 2 \mathrm{H}), 8.33-8.24(\mathrm{~m}, 2 \mathrm{H}), 8.12(\mathrm{~d}, J=4.0 \mathrm{~Hz}$, $1 \mathrm{H}), 8.04(\mathrm{~d}, J=15.3 \mathrm{~Hz}, 1 \mathrm{H}), 7.91(\mathrm{ddd}, J=8.7,6.9,1.5 \mathrm{~Hz}, 1 \mathrm{H}), 7.84(\mathrm{t}, J=$ $7.5 \mathrm{~Hz}, 1 \mathrm{H}), 7.71-7.63(\mathrm{~m}, 3 \mathrm{H}), 7.42-7.33(\mathrm{~m}, 4 \mathrm{H}), 7.18-7.08(\mathrm{~m}, 6 \mathrm{H})$, $7.02-6.95(\mathrm{~m}, 2 \mathrm{H}), 5.41(\mathrm{t}, J=8.1 \mathrm{~Hz}, 2 \mathrm{H}), 2.87(\mathrm{t}, J=6.3 \mathrm{~Hz}, 2 \mathrm{H}), 2.45$ (s, 2H). ${ }^{13} \mathrm{C}$ NMR (101 MHz, DMSO) $\delta 169.87,151.36,148.26,146.45,140.05$, 137.42, 136.72, 135.98, 133.60, 130.26, 129.92, 129.81, 129.33, 128.32, 127.87, 127.11, 125.98, 125.04, 124.96, 124.10, 122.34, 122.09, 121.91, 119.95, 111.12, 50.67, 47.17, 25.30. HRMS (ESI): $\mathrm{m} / \mathrm{z}$ calcd for $\mathrm{C}_{38} \mathrm{H}_{30} \mathrm{~N}_{2} \mathrm{O}_{3} \mathrm{~S}_{3}[\mathrm{M}-\mathrm{H}]^{+}, 657.14$; found, 657.3669 .

Preparation and Characterization of the Nanoparticles. AIEgens $(1.0 \mathrm{mg})$, DSPE-PEG ${ }_{2000}(6.5 \mathrm{mg})$ and $\mathrm{NH}_{2}$-PEG-FA (3.5mg) were dissolved in DMSO (1 $\mathrm{mL})$. The obtained DMSO solution was added into water $(5 \mathrm{~mL})$ accompanied with sonication using a microtip probe sonicator $(220 \mathrm{~W})$, followed by continuative sonication of the mixture for another 120s. Dialysis membrane 
(Molecular Weight Cut Off $(\mathrm{MWCO}=8000-14000)$ ) was used to remove DMSO in the dark for $48 \mathrm{~h}$ at room temperature to collect the NPs. After that, the solution in the bag was withdrawn and centrifuged at $2500 \mathrm{rpm}$ for $15 \mathrm{~min}$ to remove free NS-STPA not encapsulated. At last, the obtained supernatant was freeze-dried and NS-STPA NPs was obtained. The diameter, polydispersed index (PDI), and Z-potential of the nanoparticles were recorded by a Zetasizer Nano ZS instrument. A TEM was used to characterize the nanoparticle size and morphology.

\section{Determination of the NS-STPA Encapsulation Concentration}

The UV-vis absorption intensity of a series of NS-TPA or NS-STPA solutions in DMSO at $510 \mathrm{~nm}$ or $535 \mathrm{~nm}$ was measured. The standard curve of the NS-TPA or NS-STPA UV-vis absorption intensity with concentration was obtained. The amount of NS-TPA or NS-STPA encapsulated in the nanoparticles was ciphered from the standard curve.

\section{Photostability and photobleaching of Nanoparticles}

The aqueous solution of NS-STPA NPs (NS-STPA, $50 \mu \mathrm{M}$ ) and NS-TPA NPs (NS-TPA, $50 \mu \mathrm{M}$ ) were subjected to repeated irradiation on-off cycles by the $660 \mathrm{~nm}$ laser $\left(0.2 \mathrm{~W} / \mathrm{cm}^{2}\right)$.

\section{Thermal performance measurement}

The DMSO solution of NS-STPA or NS-TPA with the concentration of 100 $\mu \mathrm{M}$ was continuously exposed to a $660 \mathrm{~nm}$ laser at a power density of 0.2 $\mathrm{W} / \mathrm{cm}^{2}$ for $10 \mathrm{~min}$. The temperature was measured every $10 \mathrm{sec}$ and stopped until the temperature nearly reached to a plateau. Similar methods were conducted to assess the photothermal ability of NS-STPA NPs and NS-TPA NPs in the water. Pure DMSO and water under the same condition acted as the controls, respectively. Moreover, the aqueous solutions of NS-STPA NPs with 
different concentrations $\left(12.5 \times 10^{-5}, 10.0 \times 10^{-5}, 6.5 \times 10^{-5}, 3.0 \times 10^{-5} \mathrm{M}\right)$ were uninterruptedly exposed at a $660 \mathrm{~nm}$ laser with a power density of $0.2 \mathrm{~W} / \mathrm{cm}^{-2}$ for $10 \mathrm{~min}$, the solutions of NS-STPA NPs (NS-STPA, $100 \mu \mathrm{M}$ ) with different laser intensities $\left(0.2,0.4,0.6 \mathrm{~W} / \mathrm{cm}^{-2}\right)$ were investigated respectively. Similar methods were used to assess the photothermal ability of NS-STPA with different concentrations and different laser intensities in DMSO. Furthermore, the photothermal conversion efficiency $(\eta)$ of NS-STPA NPs in aqueous solution was calculated according to the literature:1,2

$$
\eta=\frac{h S\left(T_{\max }-T_{\text {surr }}\right)-Q_{\text {Dis }}}{I\left(1-10^{-A_{660}}\right)}
$$

where $\mathrm{S}$ is the surface area of the container, $\mathrm{T}_{\max }$ is the maximum steady state temperature, $\mathrm{Q}_{\mathrm{Dis}}$ represents heat dissipated from the laser mediated by the solvent and container. $I$ is the incident laser power, and $A_{660}$ is the absorbance of the sample at $660 \mathrm{~nm}$. The value of hS is obtained from Equation (3):

$$
\tau=\frac{\mathrm{mc}}{h S}
$$

$\mathrm{m}$ is the mass of the solution containing the photoactive material, $\mathrm{c}$ is the heat capacity $\left(4.2 \mathrm{~J} \mathrm{~g}^{-1}\right)$ of the solution, and $\tau$ is the associated time constant, which can be determined from Equation (4):

$$
t=-\tau \ln (\theta)=-\tau \ln \left(\frac{T_{t}-T_{\text {surr }}}{T_{\max }-T_{\text {surr }}}\right)
$$

where, $\mathrm{t}$ is the cooling time points after continuous irradiation for $10 \mathrm{mins}, \mathrm{T}_{\mathrm{t}}$ is the corresponding temperature of NS-STPA NPs during the cooling stage.

\section{Photothermal Stability of NS-STPA NPs}

For photostability evaluation of NS-STPA NPs, aqueous solution of NS-STPA 
NPs (NS-STPA, $100 \mu \mathrm{M}$ ) exposed under laser irradiation, then it was subjected to six laser $\left(660 \mathrm{~nm}, 0.2 \mathrm{~W} \mathrm{~cm} \mathrm{~cm}^{-2}\right)$ on/off cycles, and the temperature was measured every $10 \mathrm{sec}$ and stopped until the temperature nearly reached to a plateau. A clinically used photosensitizer indocyanine green (ICG) was measured by similar operations.

\section{Detection of ROS generation in solution}

The ROS generation efficiency in solution was investigated by using the commonly DCFH-DA as indicator. After the reaction for $30 \mathrm{~min}$ in the dark in DCFH-DA with $\mathrm{NaOH}$ solution, and PBS buffer solution was then added to the reaction mixture to obtain DCFH concentrated solution and kept in the dark until use. The activated DCFH solution (DCFH, $10 \mu \mathrm{M})$ was mixed with NS-TPA NPs or NS-STPA NPs $(2 \mu \mathrm{M})$. Afterward, the mixed solution was treated with $660 \mathrm{~nm}$ laser irradiation $\left(0.2 \mathrm{~W} / \mathrm{cm}^{2}\right)$ for different time intervals. The fluorescence of indicator at $525 \mathrm{~nm}$ triggered by AIEgen-sensitized ROS was measured with a PL instrument at the excitation of $488 \mathrm{~nm}$. The ROS generation efficiency with different states of NS-STPA were investigated by using the DCFH as an indicator under similar operations $(200 \mu \mathrm{M}, \mathrm{Vc})$. The ${ }^{1} \mathrm{O}_{2}$ generation efficiency in solution was investigated by using the ABDA as an indicator. ABDA $(100 \mu \mathrm{M})$ solution was mixed with the NS-STPA NPs in water $\left(2 \mu \mathrm{M}\right.$, NS-STPA) and then exposed to laser irradiation $\left(0.2 \mathrm{~W} / \mathrm{cm}^{2}\right)$. The absorbance decrease of ABDA at $379 \mathrm{~nm}$ was recorded at continuous irradiation time to indicate the ${ }^{1} \mathrm{O}_{2}$ generation rate. A clinically used photosensitizer chlorin e6 (Ce6) was measured by similar operations. The hydroxyl radical generation efficiency in solution was investigated by using the $\mathrm{HPF}$ as an indicator. PBS buffer solution containing $5 \mu \mathrm{M}$ HPF was added with NS-STPA NPs ( $2 \mu \mathrm{M}$, NS-STPA) and then subjected to the same laser irradiation condition. The fluorescence of indicator in a range of 500-600 nm triggered by measured with a PL instrument at the excitation of $490 \mathrm{~nm}$. The fluorescence intensity at $515 \mathrm{~nm}$ was recorded to indicate the hydroxyl radical 
generation rate.

\section{Intracellular tracking}

Human breast cancer MCF-7 cell line grown in 1640 culture medium containing $10 \% \mathrm{FBS}$ and $1 \%$ antibiotics (penicillin-streptomycin) at $37{ }^{\circ} \mathrm{C}$ in a humidified environment of $5 \% \mathrm{CO} 2$. MCF-7 cells were seeded at a suitable density in glass-bottom dish and cultured for $24 \mathrm{~h}$. The cells were then incubated with fresh medium containing NS-STPA NPs (NS-STPA, $10 \mu \mathrm{M}$ ) for $5 \mathrm{~h}$ and washed with PBS, then incubated with $4 \%(\mathrm{v} / \mathrm{v})$ formalin for $20 \mathrm{~min}$ and washed with PBS, followed by staining with diamidino-2-phenylindole for 5 min. After that, the samples were washed with PBS and imaged by CLSM to investigate the subcellular localization of NS-STPA NPs.

\section{ROS Production in Cells}

The intracellular production of ROS was detected by DCFH-DA. MCF-7 cancer cells were incubated with NS-STPA NPs $(15 \mu \mathrm{M})$ for 12 hours. Then, the culturing liquid was discarded, and the cell was washed by using PBS buffer. Then, $5 \mu \mathrm{M}$ of DCFH-DA was added into petri dish and cultured with for 20 min in the incubator. Afterwards, the cells were illuminated for $4 \mathrm{~min}$ $\left(0.4 \mathrm{~W} / \mathrm{cm}^{2}\right)$. Cells were further washed with PBS buffer, and ROS was measured using CLSM.

\section{Cell viability test}

Cells were seeded in 96-well plates at a density of $10^{5}$ cells per well. After $24 \mathrm{~h}$ culture, $100 \mu \mathrm{L}$ fresh medium containing different concentrations of NS-STPA NPs was added into each well. After 48 hours later, $20 \mu \mathrm{L}$ MTT solution (5 $\mathrm{mg} / \mathrm{mL}$ in PBS) was added into each well. After 4 hours of incubation, the medium from each well was removed, $150 \mu \mathrm{L}$ DMSO was added to each well. The absorption of each well at $490 \mathrm{~nm}$ was recorded via a plate reader(n=4). 


\section{Viability of cancer cells under laser irradiation}

Cells were seeded in 96-well plates at a density of $10^{5}$ cells per well. After $24 \mathrm{~h}$ culture, $100 \mu \mathrm{L}$ fresh medium was added into each well. After 12 hours later, the culture plates were exposed to the $660 \mathrm{~nm}$ laser with different power densities for $4 \mathrm{~min}$. After 24 hours later, $20 \mu \mathrm{L}$ MTT solution $(5 \mathrm{mg} / \mathrm{mL}$ in PBS) was added into each well. After 4 hours of incubation, the medium from each well was removed, $150 \mu \mathrm{L}$ DMSO was added to each well. The absorption of each well at $490 \mathrm{~nm}$ was recorded via a plate reader $(\mathrm{n}=4)$.

\section{Phototoxicity test}

Cells were seeded in 96-well plates at a density of $10^{5}$ cells per well. After $24 \mathrm{~h}$ culture, $100 \mu \mathrm{L}$ fresh medium containing different concentrations of NS-STPA NPs was added into each well. After 12 hours later, the culture plates were exposed to the $660 \mathrm{~nm}$ laser $\left(0.4 \mathrm{~W} / \mathrm{cm}^{2}\right)$ for $4 \mathrm{~min}$. The culture plates kept in the dark were set as the control. After 24 hours later, $20 \mu \mathrm{L}$ MTT solution (5 $\mathrm{mg} / \mathrm{mL}$ in PBS) was added into each well. After 4 hours of incubation, the medium from each well was removed, $150 \mu \mathrm{L}$ DMSO was added to each well. The absorption of each well at $490 \mathrm{~nm}$ was recorded via a plate reader.

For PTT only: MCF-7 cells were co-incubated with Vitamin C (Vc) (500 $\mu \mathrm{M})$ to exclude the PDT effect.

For PDT only: After co-incubated with nanoparticles in 96 -well plates at $37^{\circ} \mathrm{C}$ in a humidified environment of $5 \% \mathrm{CO}_{2}$ for $12 \mathrm{~h}, \mathrm{MCF}-7$ cells were kept at 4 ${ }^{\circ} \mathrm{C}$ during laser irradiation to exclude the PTT effect.

\section{Calcein/PI Staining of Live/Dead Cell Induced by PDT and PTT}

MCF-7 cells were seeded and cultured in 96-well plates with $100 \mu \mathrm{L}$ of medium. MCF-7 cells were pre-incubated with different concentrations of NS-STPA NPs for $12 \mathrm{~h}$ and then exposed to $660 \mathrm{~nm}$ laser $\left(0.4 \mathrm{~W} / \mathrm{cm}^{2}\right)$ irradiation for 4 
min. After incubated for another $2 \mathrm{~h}$, cells were further washed with PBS buffer. And the cells were stained with buffer solution of Calcein AM/PI for 30 min in the medium, the cells were then imaged. Conditions: excitation wavelength: $494 \mathrm{~nm}$ for Calcein AM, $535 \mathrm{~nm}$ for PI; emission filter: 500-570 nm for FDA, $550-650 \mathrm{~nm}$ for PI.

\section{Animal and Tumor Models}

BALB/c nude mice ( $\sim 8$ weeks old). All animals were acclimatized to the animal facility for one week prior to experimentation and housed under pathogen-free conditions. Tumor-bearing mice were prepared by subcutaneous injection of $100 \mu \mathrm{L}$ of $4 \mathrm{~T} 1$ cells $\left(5 \times 10^{5}\right)$ in PBS buffer into the right flank of nude mice. The MCF-7 tumor-bearing mice were subsequently used when the tumor volumes reached about $100 \mathrm{~mm}^{3}$.

\section{In vivo NIR fluorescence and photothermal imaging}

The MCF-7 tumor-bearing mice were administered with NS-STPA NPs in PBS at a dose of $50 \mu \mathrm{g}$ NS-STPA, per mouse via tail vein. Then, at $0,6,12$ and $24 \mathrm{~h}$ post-injection, the mice were anesthetized using $2 \%$ isoflurane in oxygen and the in vivo images were taken on IVIS Spectrum in vivo Imaging System (PerkinElmer, USA). In an attempt to evaluate the tissue distributions of NS-STPA NPs, the mice were sacrificed at $24 \mathrm{~h}$ post-injection. Major organs (heart, liver, spleen, lung and kidney) and tumor were excised, followed by washing the surface with saline for fluorescence imaging and quantitative analyses. Mice injected with PBS under the same irradiation condition was used as the control.

For in vivo photothermal imaging, the infrared thermal images of mice were acquired by using an IR camera during the irradiation of $660 \mathrm{~nm}$ laser $(0.4$ $\mathrm{W} / \mathrm{cm}^{2}$ ) for $4 \mathrm{~min}$ at $12 \mathrm{~h}$ after administration with NS-STPA NPs. Mouse injected with saline under the same irradiation condition was used as the 
control.

\section{In vivo phototherapeutic study}

To investigate the antitumor potency of NS-STPA NPs, the anticancer experiment was carried out using mice with MCF-7 tumors and administration through tail vein. All twelve mice were divided into four groups, three mice from each group: group I (PBS group), administration with PBS $(50 \mu \mathrm{L})$ alone; group II (PBS + laser group), PBS administration $(50 \mu \mathrm{L})$ followed by laser irradiation (660 $\left.\mathrm{nm}, 0.4 \mathrm{~W} / \mathrm{cm}^{2}, 4 \mathrm{~min}\right)$ after $12 \mathrm{~h}$ of dosing; group III

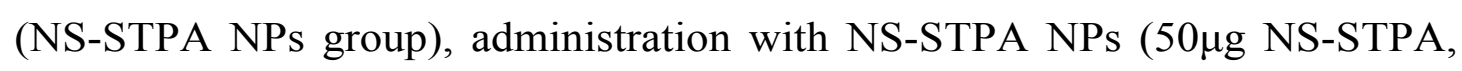
$50 \mu \mathrm{L}$ ) alone; group IV (NS-STPA NPs + laser group), administration with NS-STPA NPs $(50 \mu \mathrm{g}$ NS-STPA, $50 \mu \mathrm{L})$ and followed by laser irradiation (660 $\mathrm{nm}, 0.4 \mathrm{~W} / \mathrm{cm}^{2}, 4 \mathrm{~min}$ ) after $12 \mathrm{~h}$ of dosing. All groups were given three times of PDT treatment, and every treatment is one day apart. During treatments, the tumor size and body weight of each mouse were monitored and recorded every 2 days. The tumor size was measured by a vernier caliper, and the tumor volume (V) was estimated using the following formula: $\mathrm{V}=$ (length $\times$ width $\left.^{2}\right) / 2$.

\section{Hemolysis Test}

The release of hemoglobin from mice blood cells was used to evaluate the hemolytic activities of NS-STPA NPs. Briefly, red blood cell suspension mixed with phosphate buffer saline (PBS) and $\mathrm{H}_{2} \mathrm{O}$ served as negative control (no hemolysis) and positive control (100\% hemolysis), respectively. After that, PBS solution with different concentration of NS-STPA NPs from $1 \mu \mathrm{M}$ to 50 $\mu \mathrm{M}$ were added into the mixture of red blood cell suspension. After being kept at $37^{\circ} \mathrm{C}$ for $0.5 \mathrm{~h}$ in the dark, all the samples were centrifuged for $5 \mathrm{~min}$, the absorbance of released hemoglobin in supernatants was measured at $570 \mathrm{~nm}$ using the UV-Vis-NIR spectrometer. The percent of hemolysis was calculated 


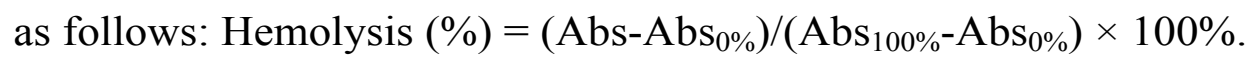

\section{Histological analyses}

All the mice were sacrificed after complete treatment of 21 days. Tumors were dissected from the mice, and the tumors were photographed to visually observe the final treatment outcomes. Major organs (heart, liver, spleen, lung and kidney) and the tumors were dissected from the mice, and the tumors and were photographed to visually observe the final treatment outcomes. After the tissues were fixed in $4 \%(\mathrm{v} / \mathrm{v})$ formalin overnight, they were embedded in paraffin and sectioned at $3 \mu \mathrm{m}$ thickness. The sections were then subjected to H\&E or TUNEL staining for histopathological evaluation. 
Supporting information

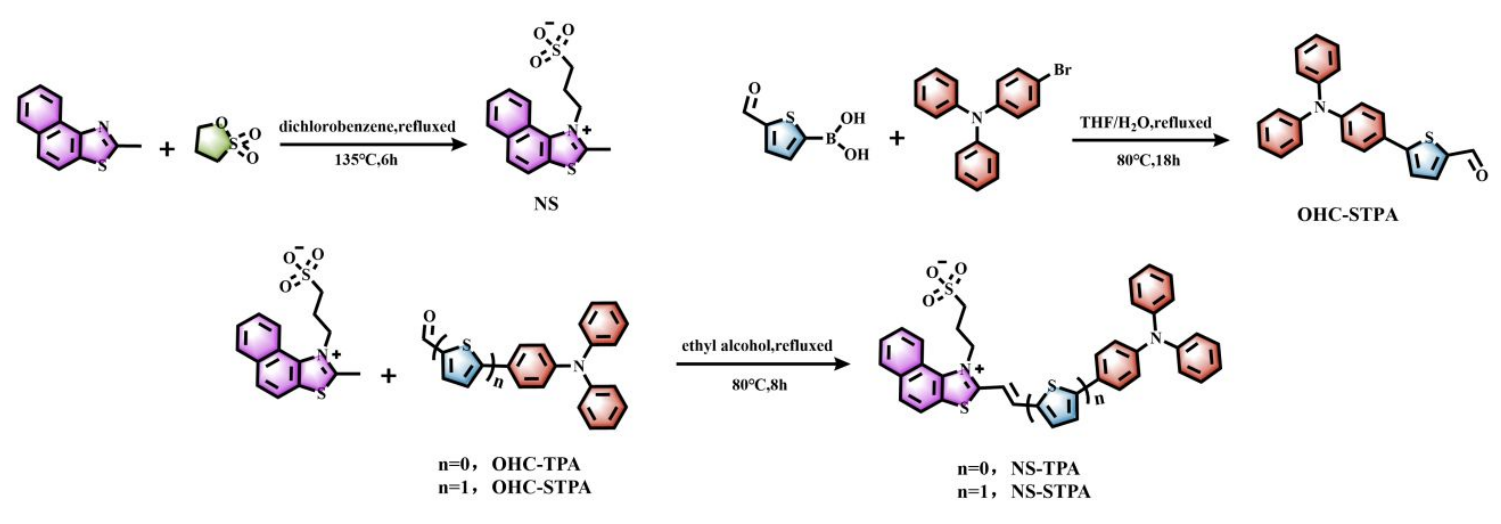

Scheme S1. The synthetic routes to NS-TPA and NS-STPA.
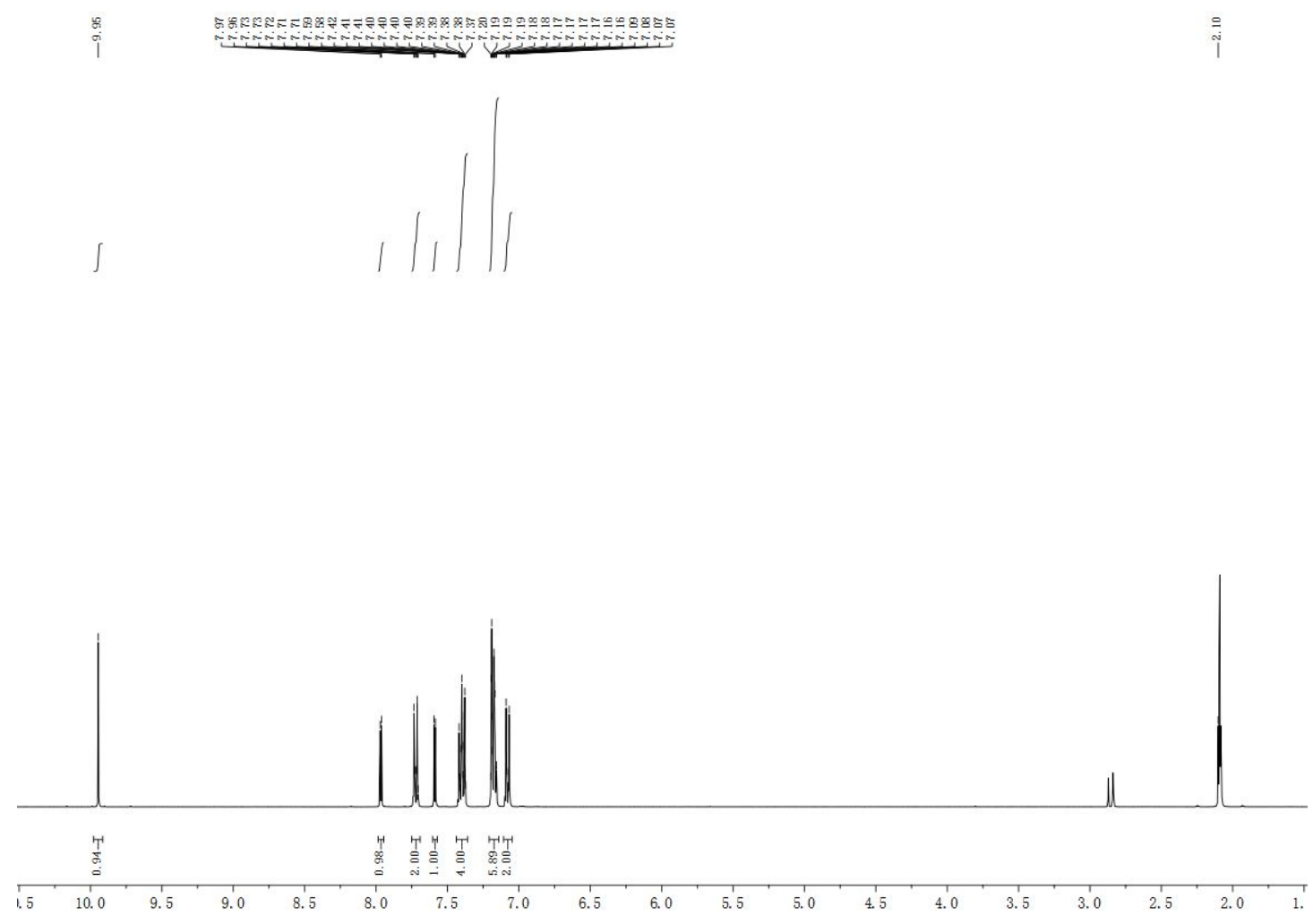

Figure S1. ${ }^{1} \mathrm{H}$ NMR spectra of CHO-STPA

S12 


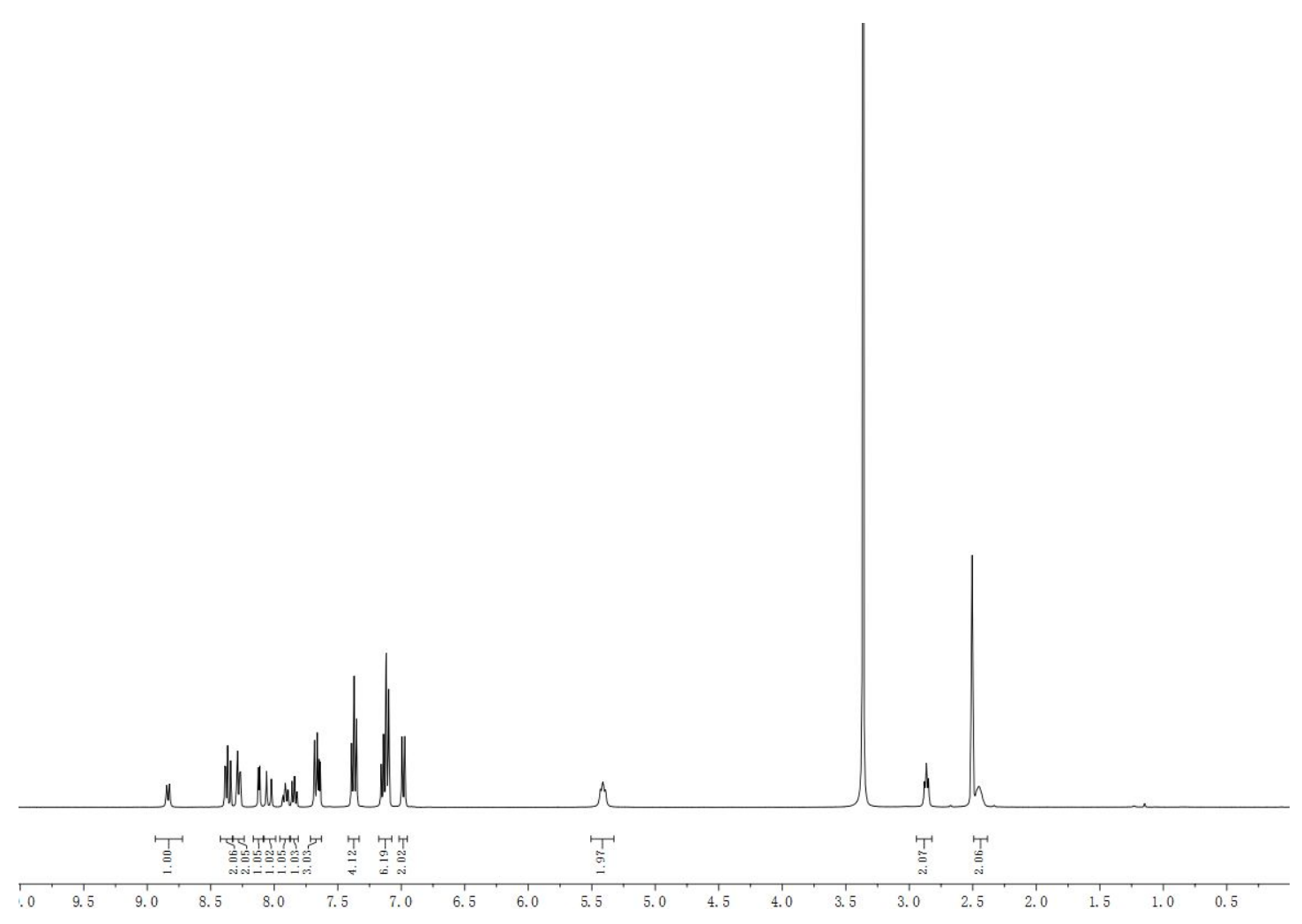

Figure S2. ${ }^{1} \mathrm{H}$ NMR spectra of NS-STPA
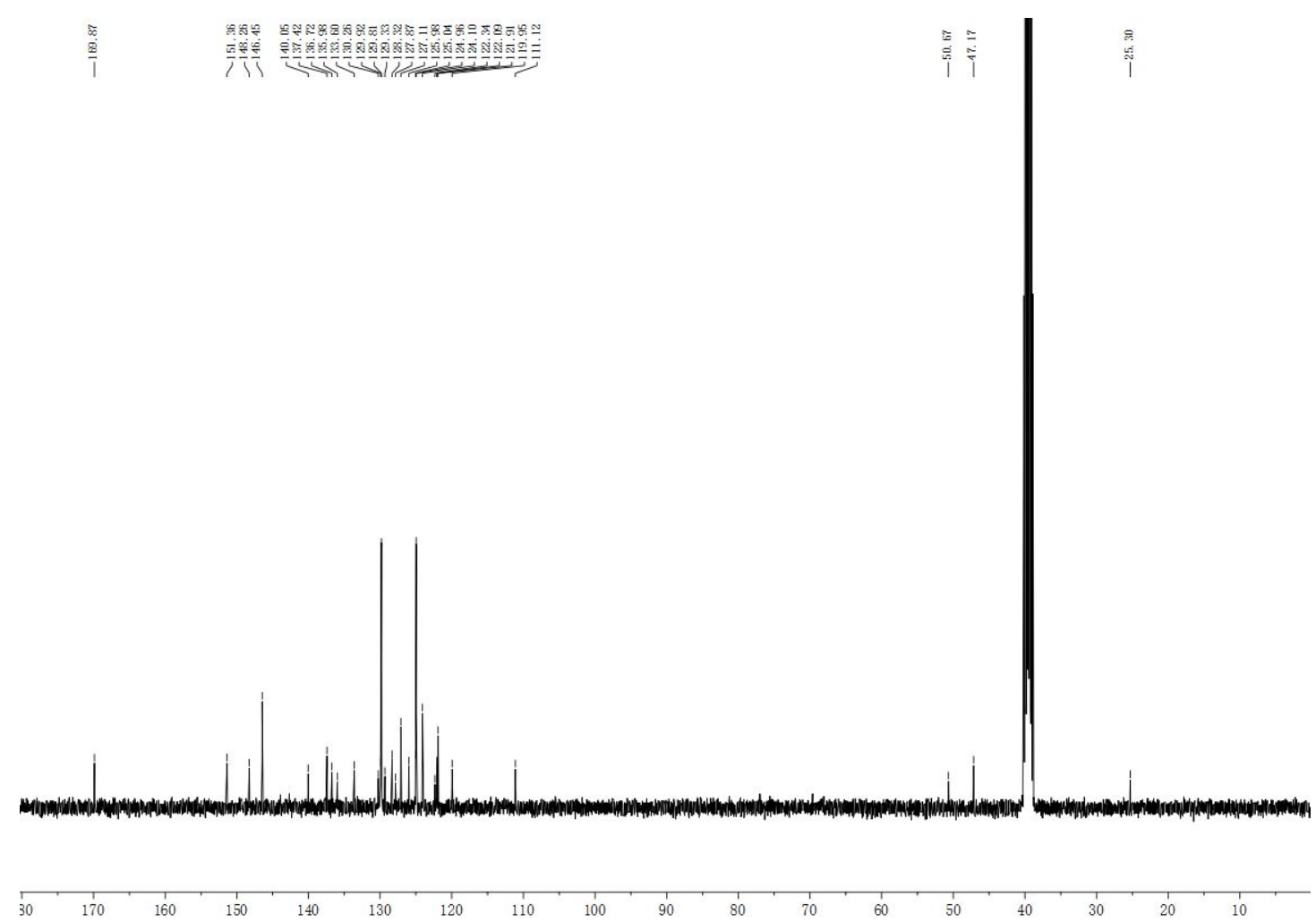

Figure S3. ${ }^{13} \mathrm{C}$ NMR spectra of NS-STPA 


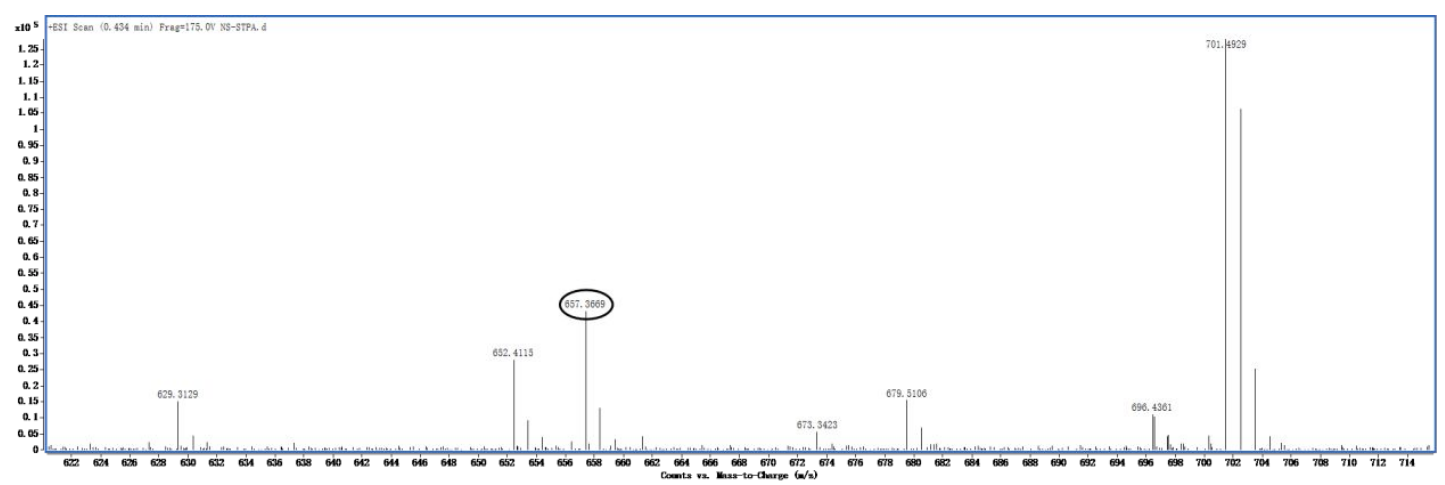

Figure S4. HRMS spectrum of NS-STPA.
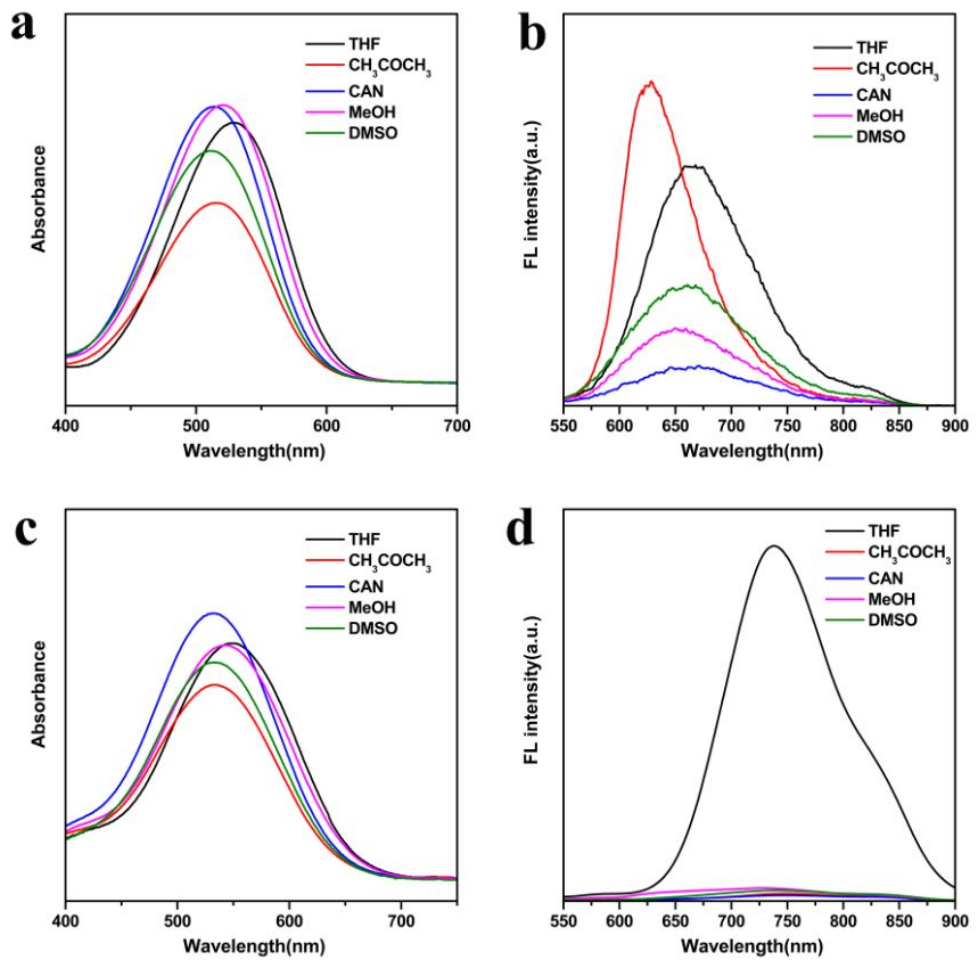

Figure S5. The absorption and emission spectra of NS-TPA (a, b), NS-STPA (c, d) in different solvents polarities (Concentration: $1.0 \times 10^{-5} \mathrm{M}$ ). 

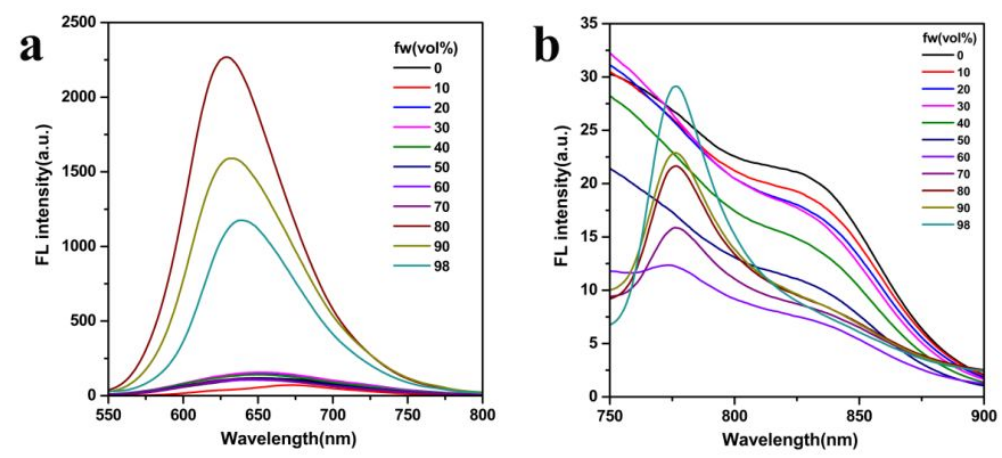

Figure S6. FL spectra of NS-TPA (a) and NS-STPA (b) in DMSO/ $\mathrm{H}_{2} \mathrm{O}$ mixtures $\left(1.0 \times 10^{-5}\right.$ M) with $\mathrm{H}_{2} \mathrm{O}\left(f_{\mathrm{w}}\right)$.
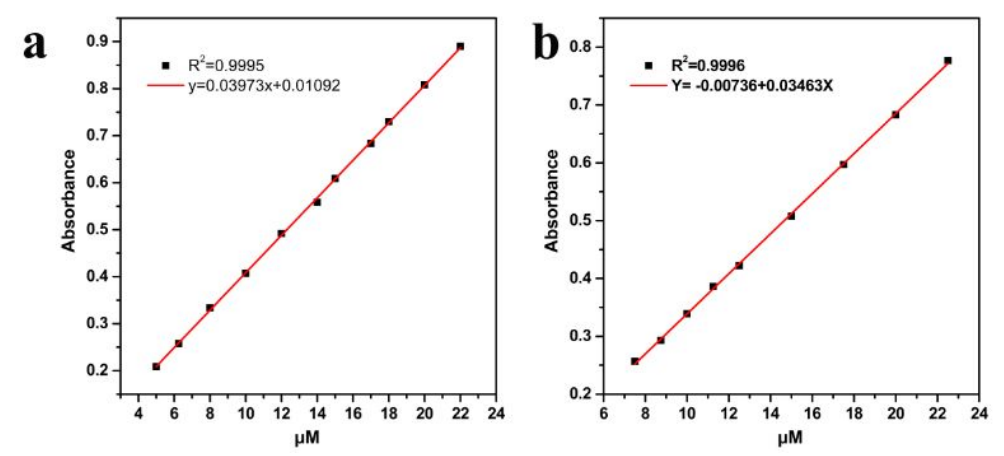

Figure S7. The standard curve between the concentration of NS-TPA (a) and NS-STPA (b) and absorption intensity measured by UV-vis absorption intensity.

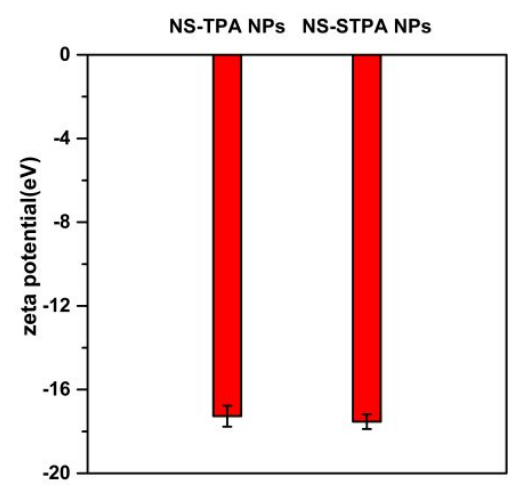

Figure S8. Zeta potentials ( $\xi$-potentials) of NS-TPA NPs and NS-STPA NPs in aqueous solution, respectively. 

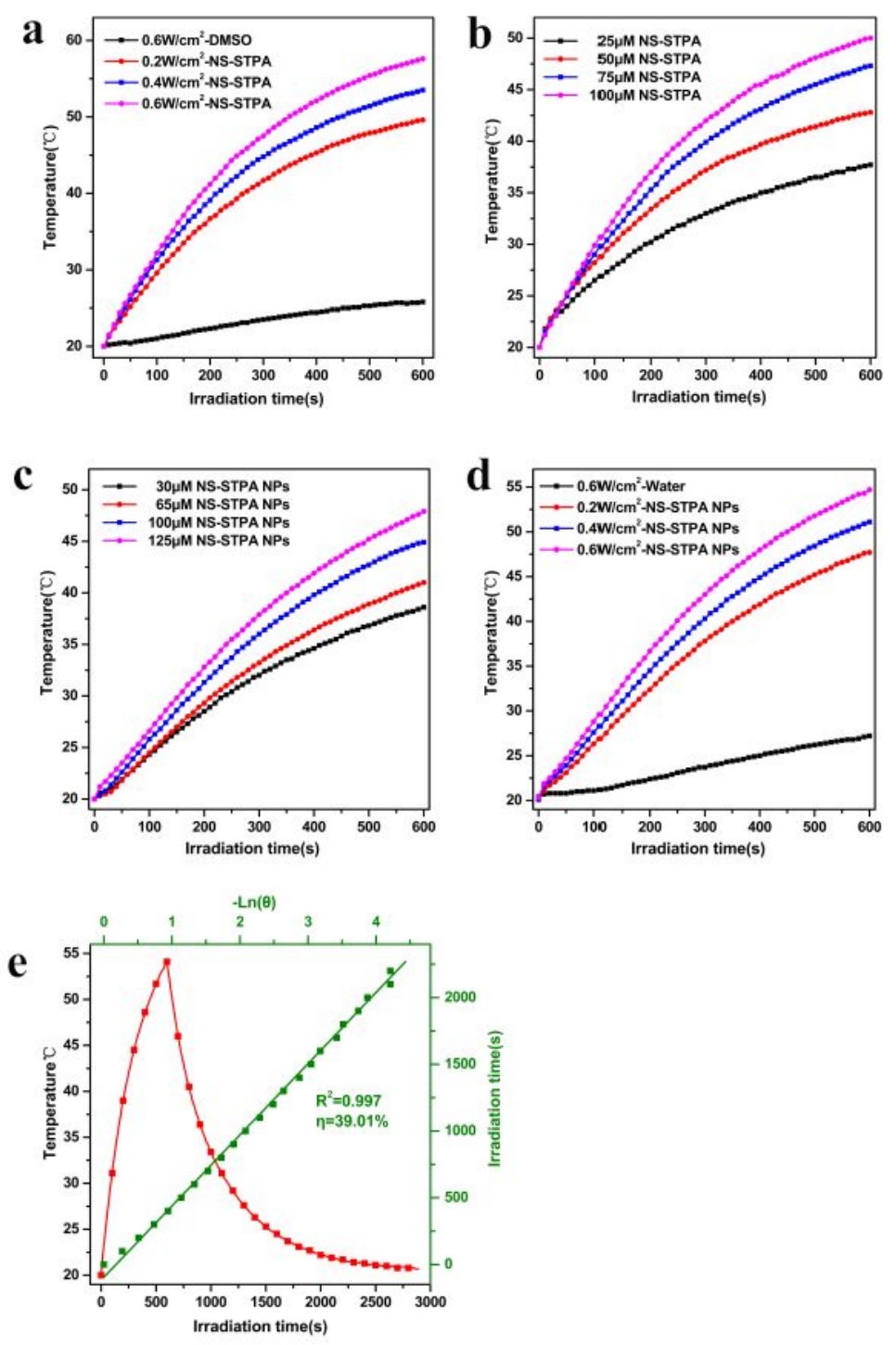

Figure S9. Corresponding heating curves for different laser power densities $(100.0 \mu \mathrm{M})$ (a) and different concentrations $\left(0.2 \mathrm{~W} / \mathrm{cm}^{2}\right)$ (b) of NS-STPA in DMSO. Corresponding heating curves for different concentrations $\left(0.2 \mathrm{~W} / \mathrm{cm}^{2}\right)(\mathrm{c})$ and different laser power densities $(125.0 \mu \mathrm{M})$ (d) of NS-STPA NPs in aqueous solution under $660 \mathrm{~nm}$ laser irradiation. (e) Photothermal performance of NS-STPA NPs (NS-STPA, $100.0 \mu \mathrm{M}, 0.6 \mathrm{~W} / \mathrm{cm}^{2}$ ) by cooling to room temperature with linear analysis. 


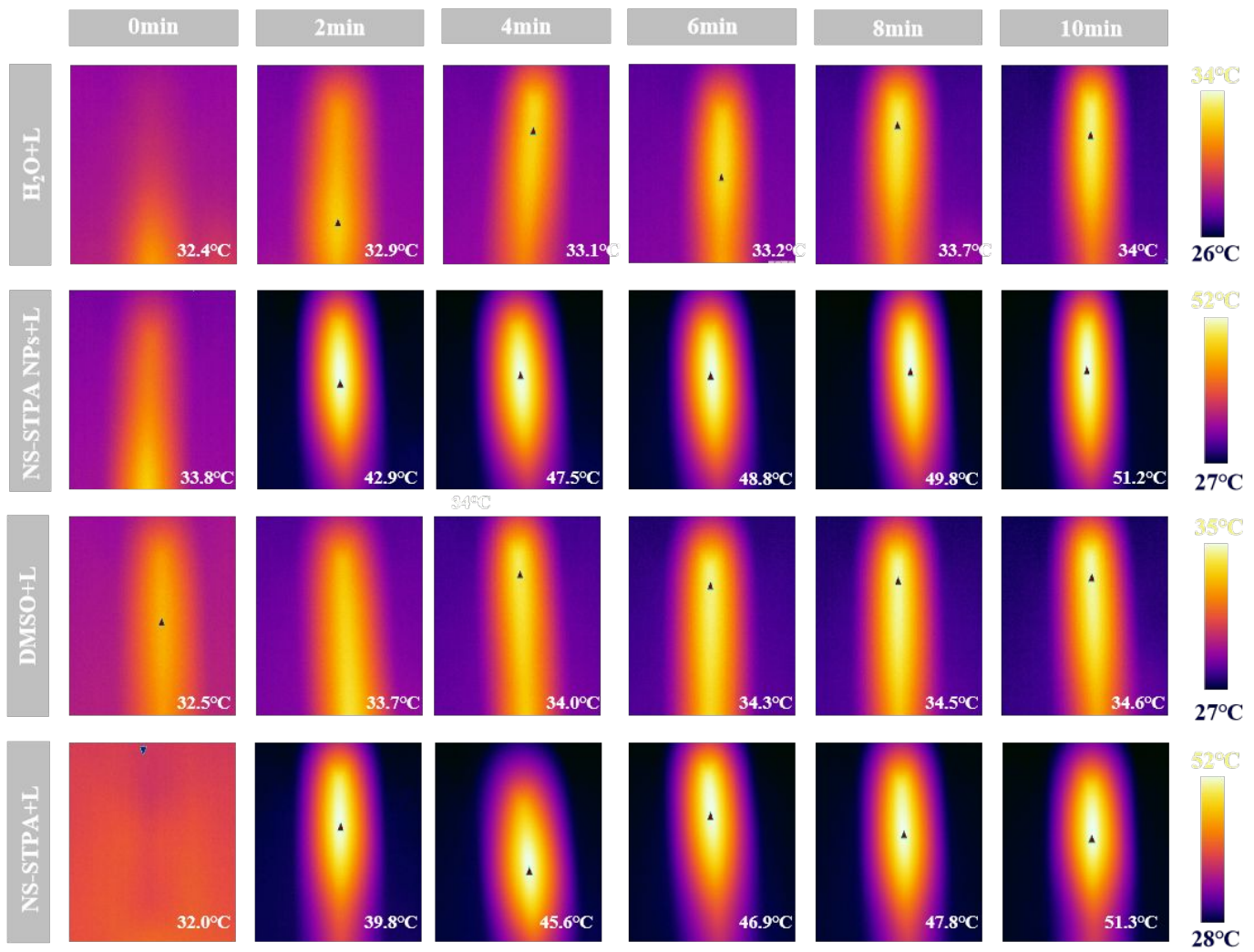

Figure S10. IR thermal images of AIEgens $(100.0 \mu \mathrm{M})$ at different times under $660 \mathrm{~nm}$ laser irradiation $\left(0.2 \mathrm{~W} / \mathrm{cm}^{2}\right)$.
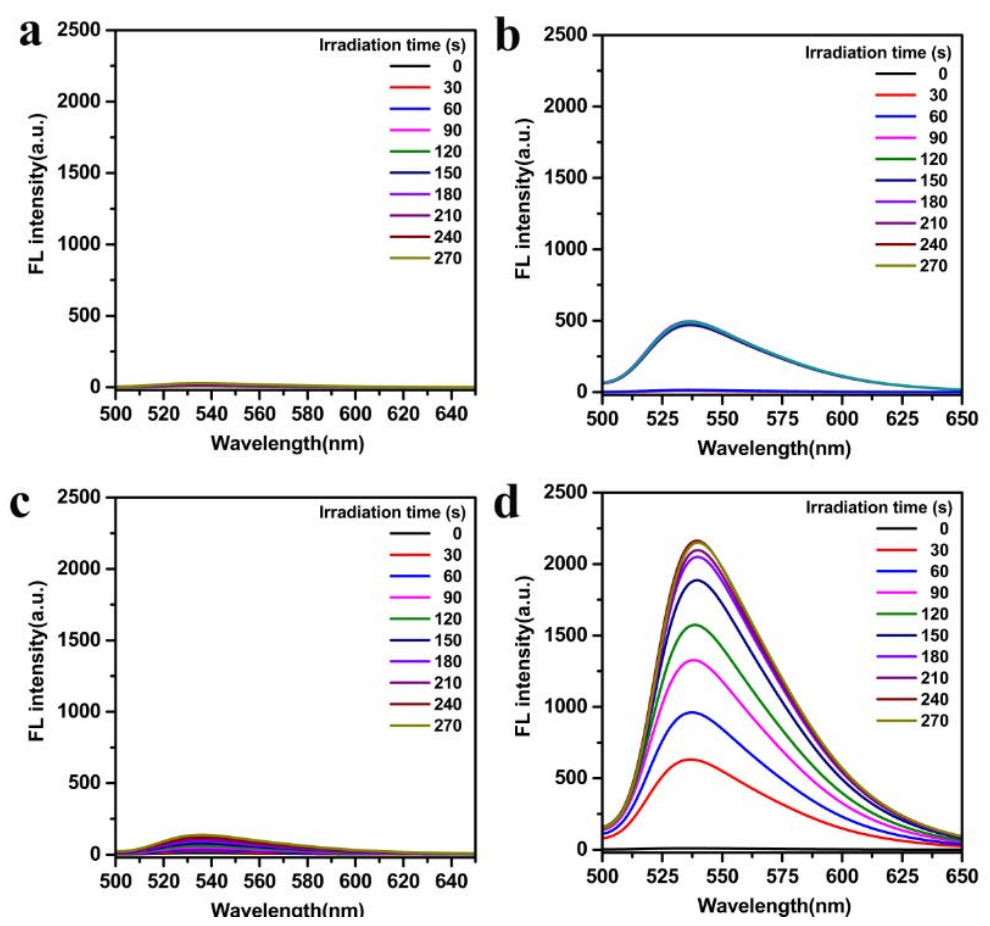

Figure S11. FL spectra of mixtures of DCFH $(10.0 \mu \mathrm{M})$ and AIEgens $(2.0 \mu \mathrm{M})$ after $660 \mathrm{~nm}$ laser irradiation for different times: (a) Blank, (b) Ce6, (c) NS-TPA NPs, (d) NS-STPA NPs. 

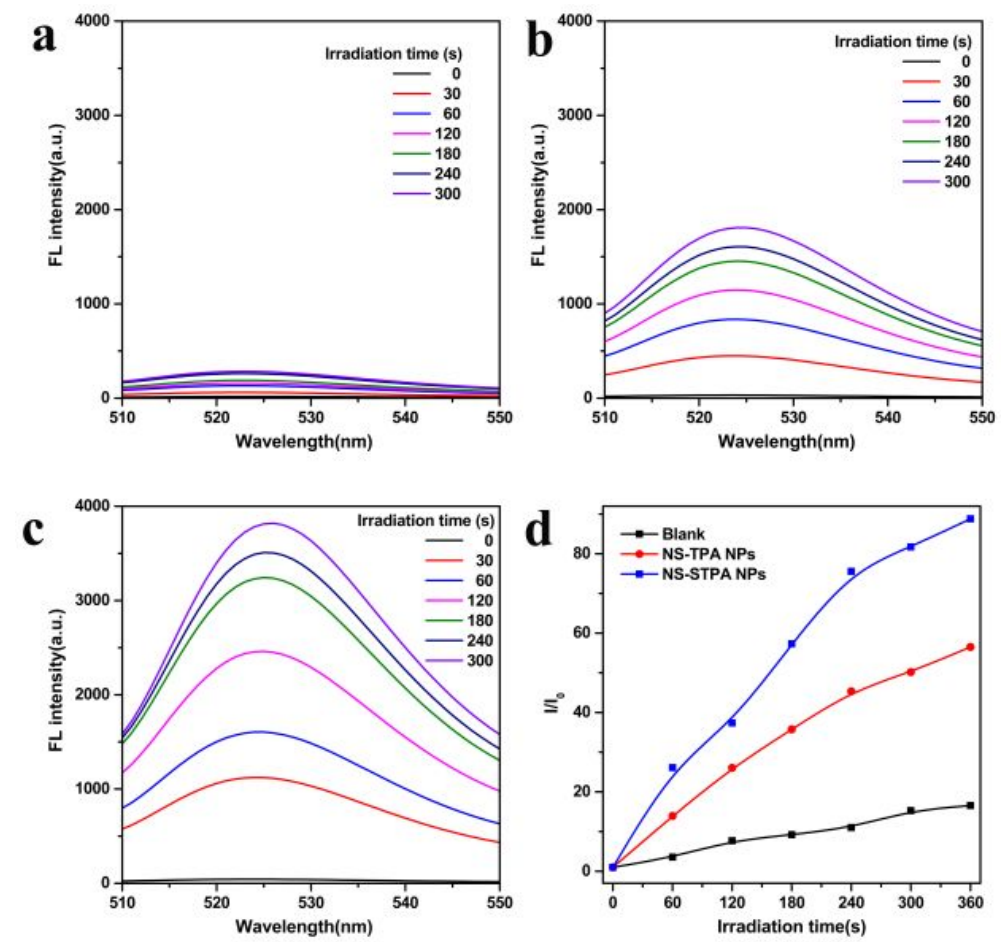

Figure S12. FL spectra of mixtures of DCFH $(10.0 \mu \mathrm{M})$ and AIEgens $(2.0 \mu \mathrm{M})$ after $530 \mathrm{~nm}$ laser irradiation for different times: (a) Blank, (b) NS-TPA NPs, (c) NS-STPA NPs.
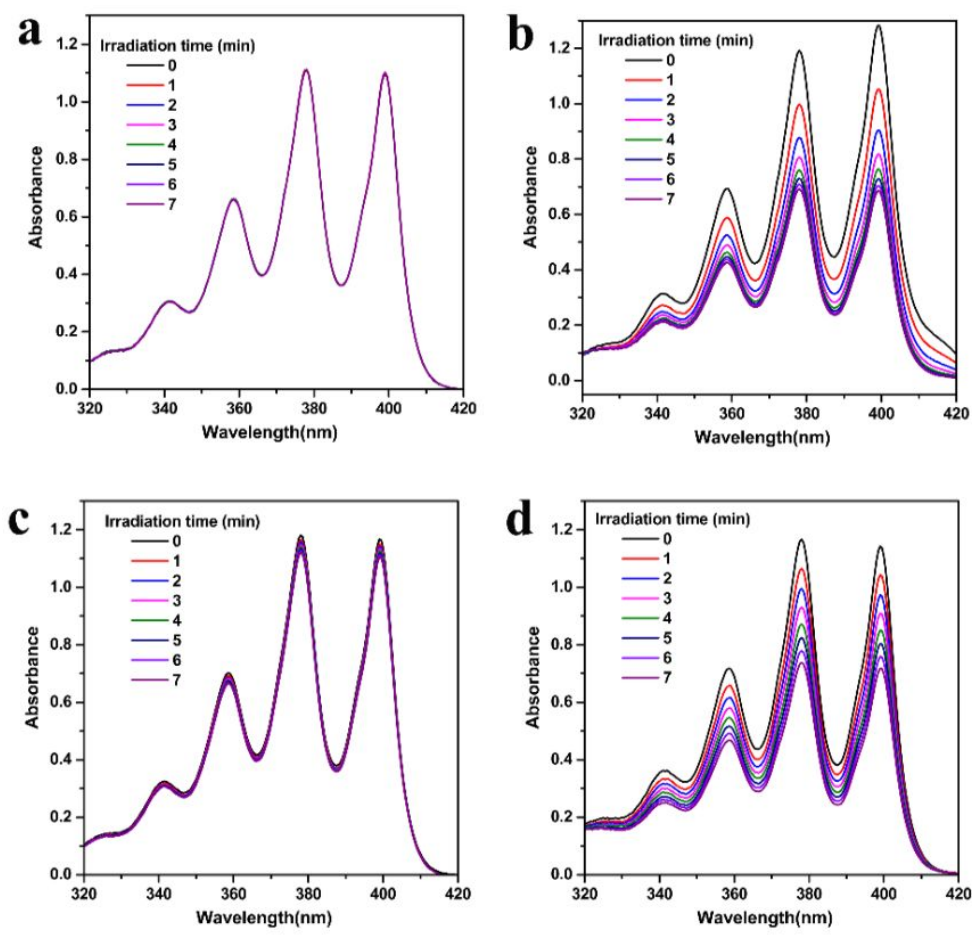

Figure S13. Absorption of ABDA $(100.0 \mu \mathrm{M})$ in the presence of (a) blank-water, (b) $\mathrm{Ce} 6$ in water, (c) NS-TPA NPs in water, (d) NS-STPA NPs in water under $660 \mathrm{~nm}$ laser irradiation for different times. 

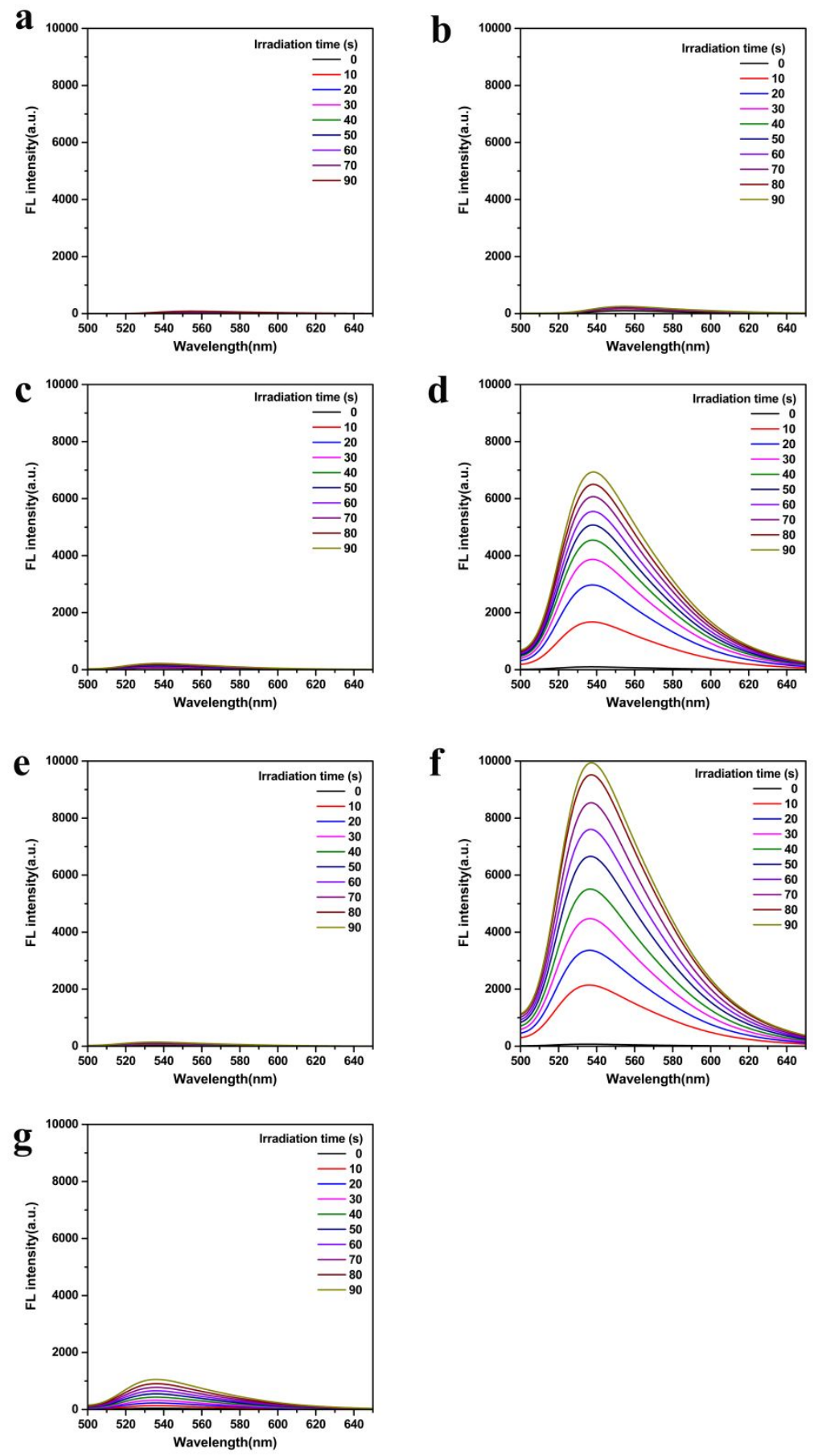

Figure S14. FL spectra of mixtures of DCFH $(10.0 \mu \mathrm{M})$ and AIEgens $(2.0 \mu \mathrm{M})$ after $660 \mathrm{~nm}$ laser irradiation for different times: (a) blank-DMSO, (b) NS-STPA in DMSO, (c) blank- $98 \% \mathrm{H}_{2} \mathrm{O}+2 \%$ DMSO, (d) NS-STPA in $98 \% \mathrm{H}_{2} \mathrm{O}+2 \%$ DMSO, (e) blank- $\mathrm{H}_{2} \mathrm{O}$, (f) NS-STPA NPs in $\mathrm{H}_{2} \mathrm{O}$, (g) NS-STPA NPs $+\mathrm{Vc}(200.0 \mu \mathrm{M})$ in $\mathrm{H}_{2} \mathrm{O}$. 

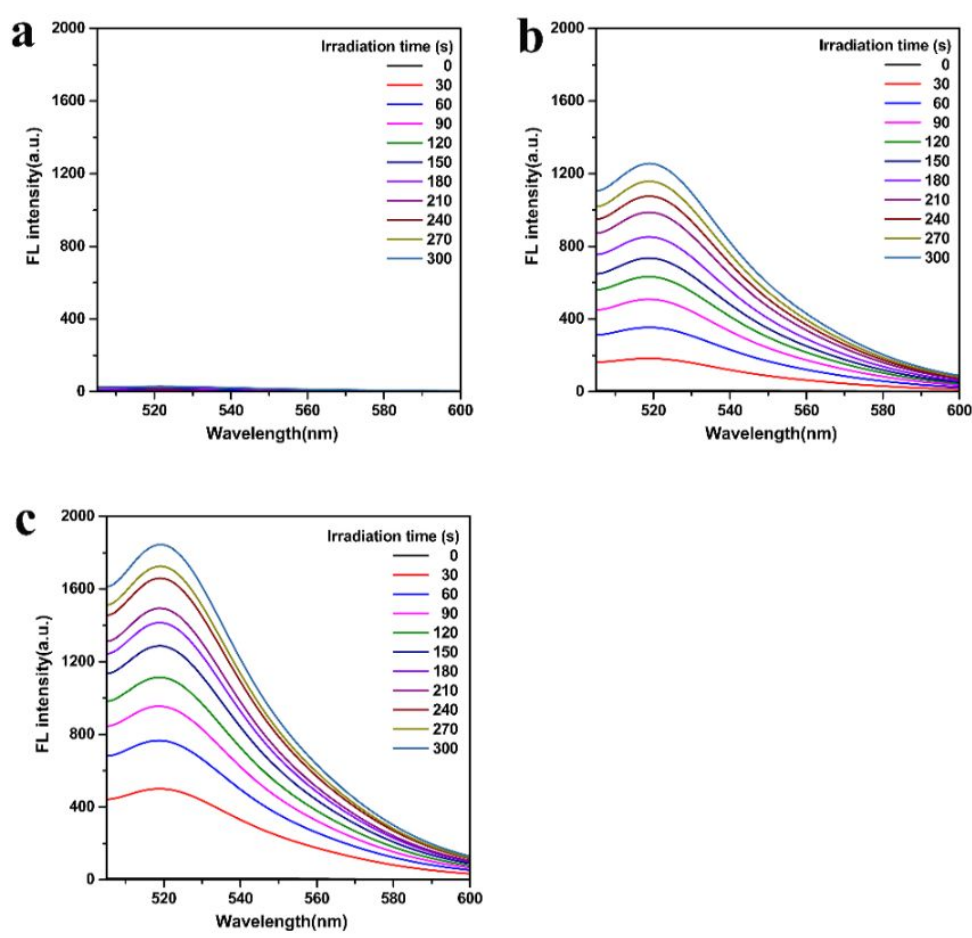

Figure S15. The plot of FL spectra for ${ }^{\bullet} \mathrm{OH}$ using HPF as fluorescence probe with (a) blank-PBS, (b) NS-STPA NPs-hypoxic, (c) NS-STPA NPs-normoxia in PBS after $660 \mathrm{~nm}$ laser $\left(0.2 \mathrm{~W} / \mathrm{cm}^{-2}\right)$ irradiation at different times.

Table S1. Calculated energy of AIEgens.

\begin{tabular}{|c|c|c|}
\hline Properties & NS-TPA & NS-STPA \\
\hline $\mathrm{S}_{0}(\mathrm{LUMO}$ to HOMO $) / \Delta E \mathrm{~g}(\mathrm{eV})$ & 2.47 & 2.08 \\
\hline $\mathrm{S}_{1}$ to $\mathrm{S}_{0} / \Delta E \mathrm{~g}(\mathrm{eV})$ & 1.80 & 1.61 \\
\hline $\mathrm{S}_{1}$ to $\mathrm{T}_{1} / \Delta E_{\mathrm{ST}}(\mathrm{eV})$ & 0.48 & 0.37 \\
\hline
\end{tabular}




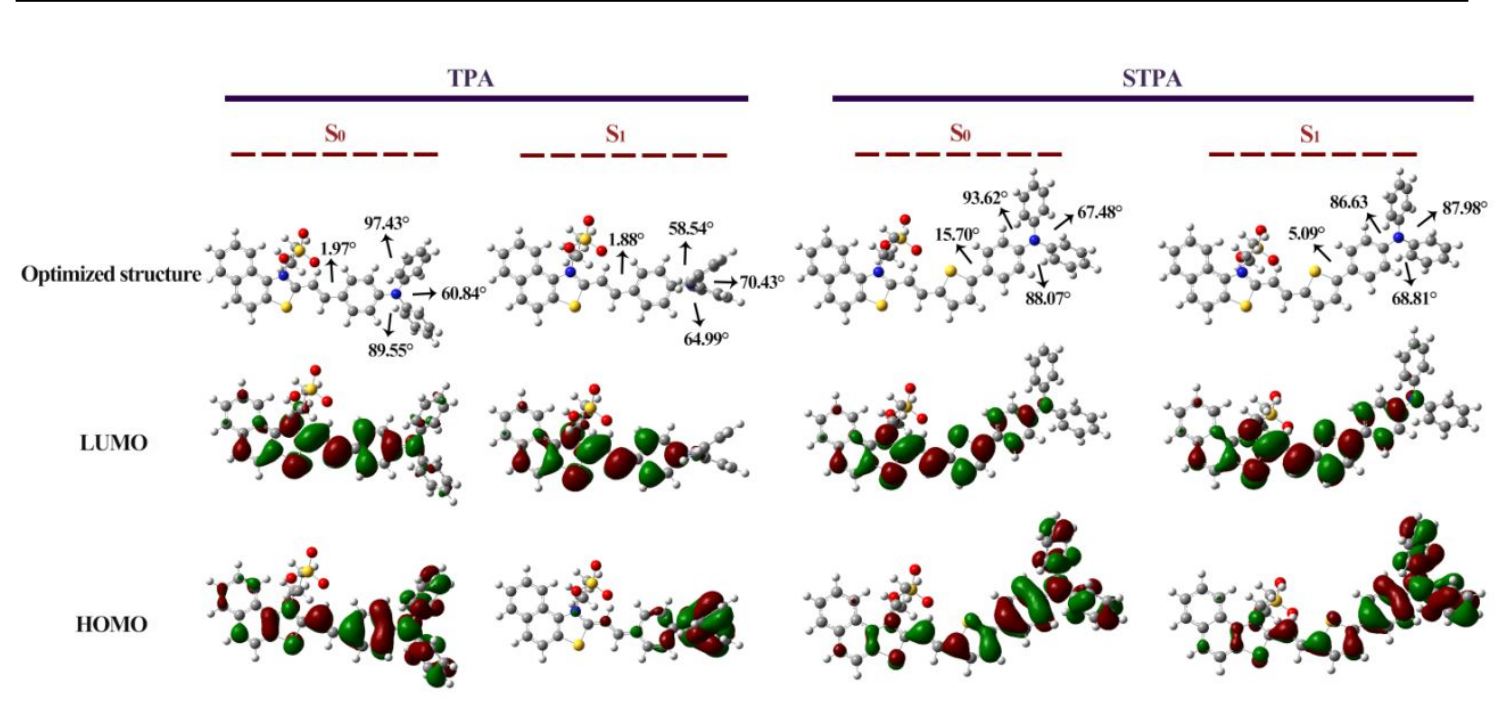

Figure S16. Molecular orbital amplitude plots of the HOMO and LUMO energy levels of NS-TPA and NS-STPA. Calculations were performed by DFT theory calculations at the B3LYP/6-31G level using the Gaussian program.

Table S2. Spin-orbit coupling matrix elements of NS-TPA in optimized structure. $<\mathrm{S}_{\mathrm{m}}\left|\mathrm{H}_{\mathrm{SO}}\right| \mathrm{T}_{\mathrm{n}}>, \mathrm{cm}^{-1}$.

\begin{tabular}{|c|c|c|c|c|c|}
\hline $\mathrm{m}$ & 1 & 2 & 3 & 4 & 5 \\
\hline 0 & 0.797496 & 0.653911 & 1.263764 & 3.501485 & 1.300154 \\
\hline 1 & 0.342345 & 0.39 & 0.53591 & 0.71007 & 0.509313 \\
\hline 2 & 0.785111 & 0.21 & 0.478644 & 0.65582 & 0.283196 \\
\hline 3 & 0.831023 & 0.739256 & 0.076158 & 0.993177 & 0.056569 \\
\hline 4 & 0.650769 & 1.027765 & 0.498899 & 0.333916 & 0.104881 \\
\hline 5 & 1.380724 & 0.320312 & 0.367015 & 0.481144 & 0.2995 \\
\hline
\end{tabular}


Table S3. Spin-orbit coupling matrix elements of NS-STPA in optimized structure. $<\mathrm{S}_{\mathrm{m}}\left|\mathrm{H}_{\mathrm{SO}}\right| \mathrm{T}_{\mathrm{n}}>, \mathrm{cm}^{-1}$.

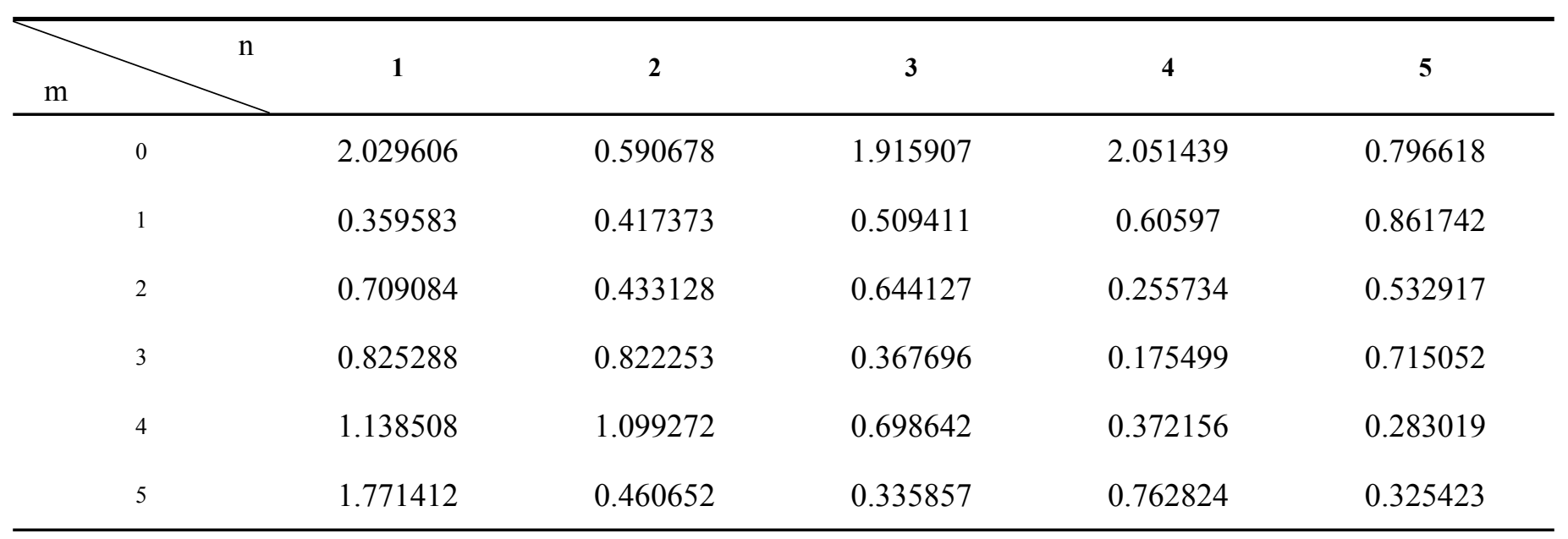

a

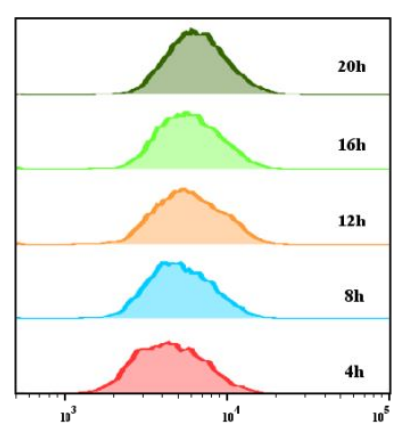

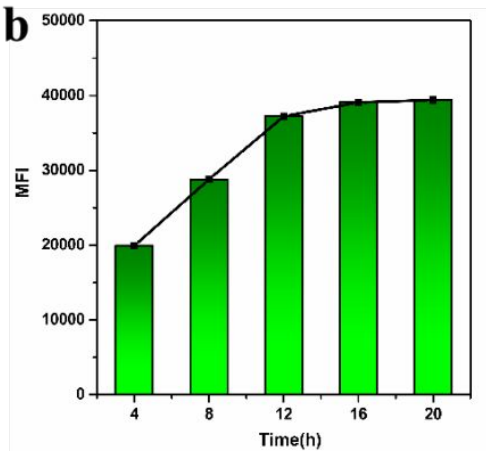

Figure S17. Flow cytometry analysis of MCF-7cells incubated with NS-STPA NPs with different time (a) and cellular median fluorescence intensity (MFI) (b). 

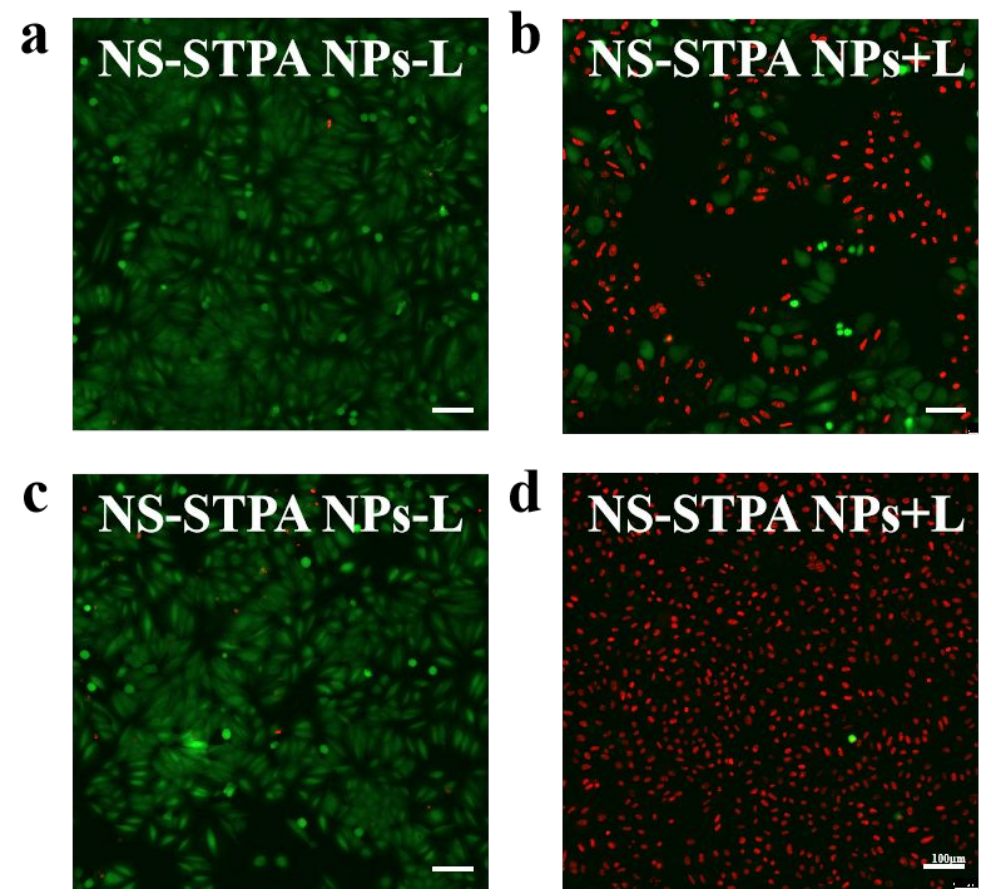

Figure S18. Live/dead staining assay of MCF-7 cells after treatments with $10.0 \mu \mathrm{M}$ (a: -L, b: $+\mathrm{L})$, and $20.0 \mu \mathrm{M}(\mathrm{c}:-\mathrm{L}, \mathrm{d}:+\mathrm{L})$ of NS-STPA NPs.
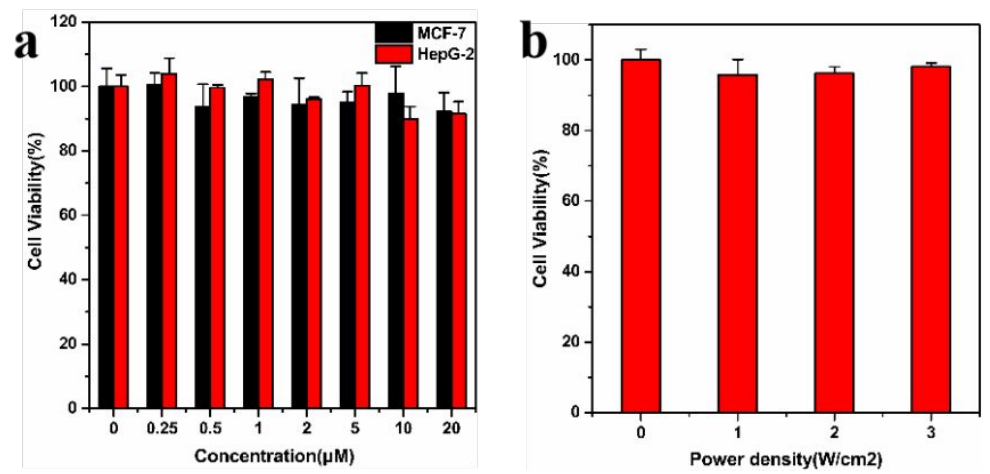

Figure S19. (a) Cell viability of HepG-2 cells and MCF-7 cells incubated with NS-STPA NPs at various concentrations in the dark determined by MTT assay (mean $\pm \mathrm{SD}, \mathrm{n}=4$ ). (b) Cell viability of MCF-7 cells under different power densities laser irradiation determined by MTT assay (mean $\pm \mathrm{SD}, \mathrm{n}=4)$. 

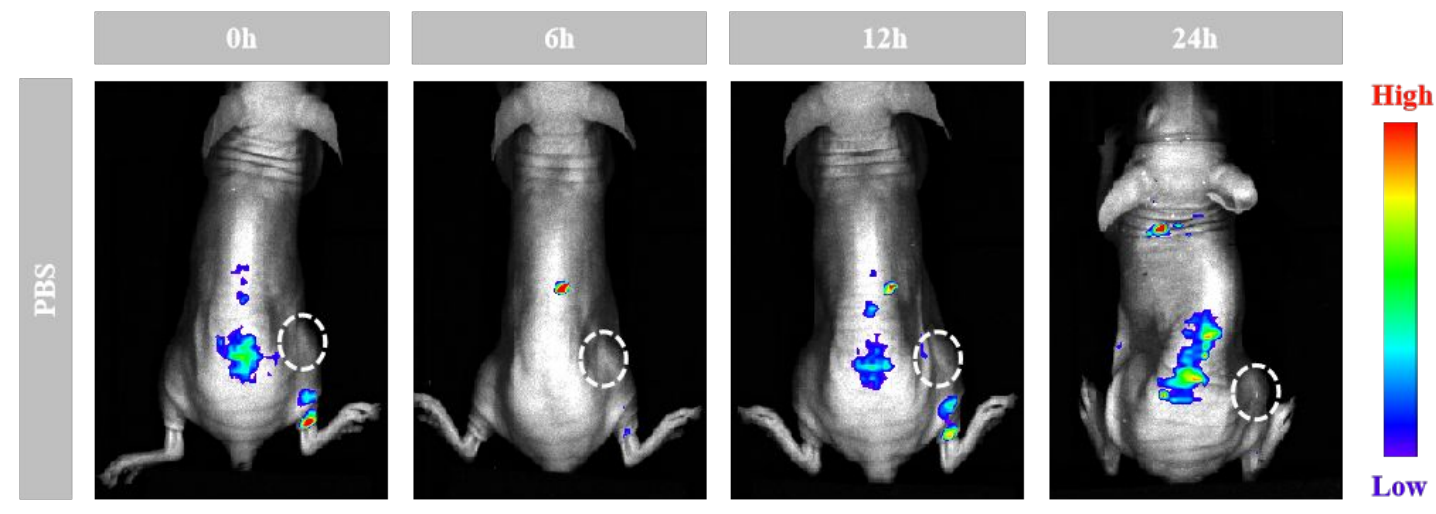

Figure S20. Fluorescence imaging of the mice at different time points after intravenous administration of PBS.
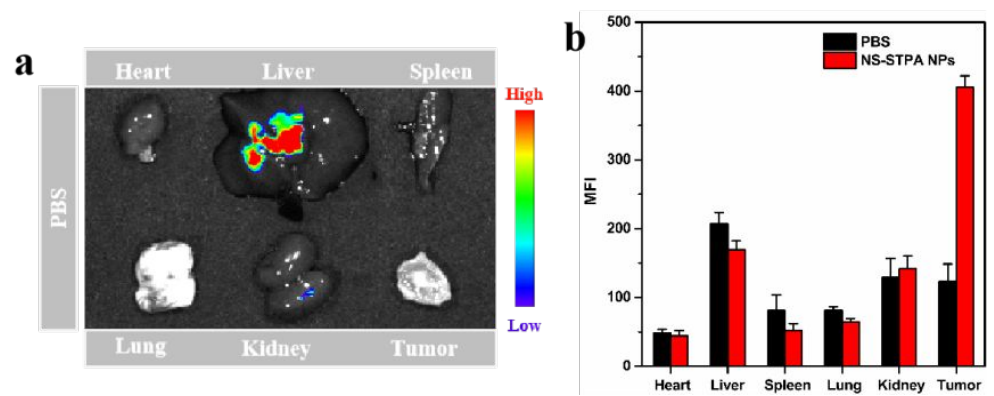

Figure S21. (a) Ex vivo fluorescence images after intravenous injection with PBS for $24 \mathrm{~h}$. (b) the corresponding mean fluorescence intensity (MFI) of tumor and major organs after intravenous injection with NS-STPA NPs and PBS for $24 \mathrm{~h}$.

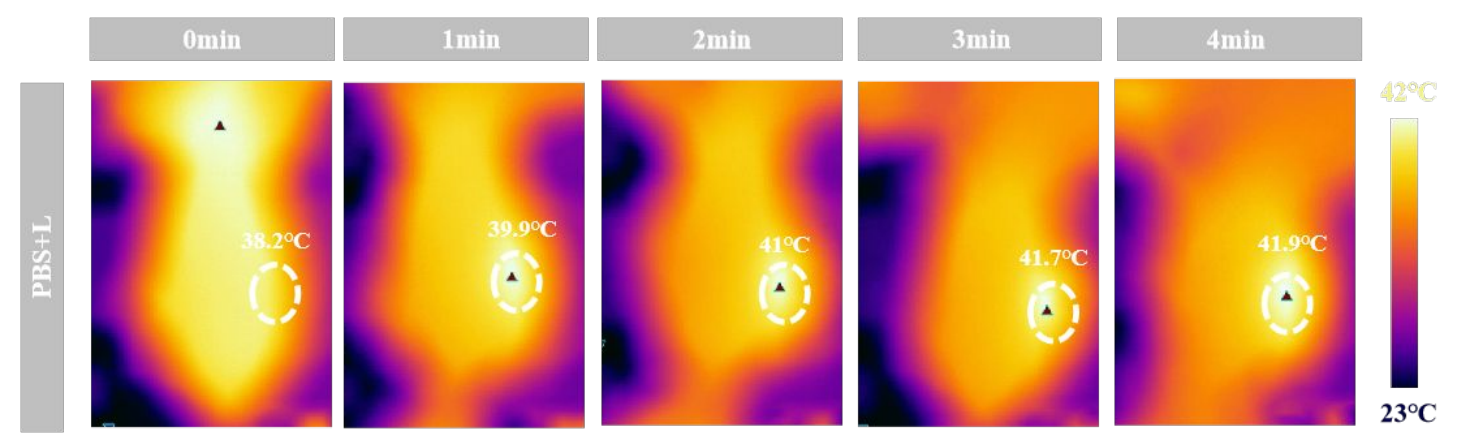

Figure S22. Thermal images, heating temperatures (at tumor sites) of tumor-bearing mice during continuous NIR irradiation at $12 \mathrm{~h}$ postinjection of PBS. 


\section{References}

(1) Tian, Q.; Jiang, F.; Zou, R.; Liu, Q.; Chen, Z.; Zhu, M.; Yang, S.; Wang, J.; Wang, J.; Hu, J.

Hydrophilic Cu9s5 Nanocrystals: A Photothermal Agent with a 25.7\% Heat Conversion Efficiency for Photothermal Ablation of Cancer Cells in Vivo. ACS nano 2011, 5, 9761-9771.

(2) Roper, D. K.; Ahn, W.; Hoepfner, M. Microscale Heat Transfer Transduced by Surface Plasmon Resonant Gold Nanoparticles. J. Phys. Chem. C. 2007, 111, 3636-3641. 